\title{
Big new forest reserve
}

\section{Cape Town}

South Africa's Minister of Environment Affairs, Gert Kotze, announced last month the establishment of a huge new conservation area on the northernmost part of the country's east coast. It will bring together the existing Lake St Lucia and Mkuze game reserves, the Sordwana Bay National Park, several state forests and the St Lucia Marine Reserve, and will include a state forest on the eastern shores of Lake St Lucia where a controversial dune mining operation for titanium has been proposed. Last week in parliament, Kotze denied that the declaration of the new conservation area was a "trade-off" for granting permission for the development, and said that the government is awaiting the outcome of an environmental impact assessment before making a final decision on the mining proposal.

The Lake St Lucia Game Reserve is, together with the Umfolozi and Hluhluwe Reserves, the oldest in Africa, having been proclaimed in 1895. Lake St Lucia is the largest estuarine system on the continent, and contains a variety of wetland and other habitats considered critical to the survival of 102 rare and endangered species. But since 1954 it has been damaged by the introduction of largescale timber plantations, which, together with water abstraction from its main source, the Mkuze River, have led to serious hypersalinity problems. These problems should soon be alleviated, as the new reserve will incorporate much of the Mkuze catchment zone, and areas under timber plantation will be replanted with indigenous vegetation.

In addition, a South African Defence Force missile-testing range at St Lucia is to be phased out. The consolidated area will be more than 275,000 hectares in size, making it the third largest reserve in South Africa. But the proposed dune-mining operation has become perhaps the country's most controversial development to date: a petition opposing it has drawn over 250,000 signatures. Prospecting and subsequent mining rights to the area were granted about 20 years ago to Richards Bay Minerals, 50 per cent of which is owned by the British-based multinational Rio Tinto Zinc company. The mining operation would bring in an estimated R5,000-R9,000 million ( $\$ 1,250-\$ 2,250$ million) over its 20 -year lifespan, and create 600 jobs in an area of high unemployment.

Richards Bay Minerals argues that 60 per cent of the 1,300 hectares due to be mined is covered by exotic pine plantations which will be replanted with natural vegetation once the operation is finished. Environmental pressure groups have countered that their main concern is less that a particular area will be mined than that power lines will have to be built across the lake, and that trucks filled with ore will travel through the reserve at a rate of one every five minutes for 24 hours a day. The National Union of Metalworkers of South Africa has been reluctant to take sides, but has expressed reservations about the way that the campaign for St Lucia has been run. "None of the environmental organizations have consulted us about the issue and some of our members are wondering if they think it is more important to save insects and animals while people have to sacrifice jobs and wages", their regional secretary, Michael Mabuyakhulu, was quoted as saying in the Weekly Mail.

Michael Cherry

\section{RADIATION EXPOSURE}

\section{More haste, less speed}

\section{London}

IN its anxiety to show that follow-up studies to the recent Gardner report are in hand, British Nuclear Fuels Limited (BNFL) has trodden on the toes of one of Britain's leading epidemiologists.

Professor Peter Smith, from the London School of Hygiene and Tropical Medicine, says he was telephoned by Roger Berry, chief medical officer for BNFL, and asked to give an independent assessment of the Gardner report. This report suggested a link between the cases of childhood leukaemia near BNFL's Sellafield nuclear plant and their fathers' occupational radiation exposure (see Nature 343, 679, 22 February 1990).

Smith sent BNFL some preliminary notes before visiting a research project in Africa, but says he stressed these "were not for general distribution or release". Shortly afterwards, BNFL issued a press release which summarized Smith's preliminary report, describing him as "BNFL's epidemiology consultant".

Smith says BNFL's behaviour was "inappropriate", and is particularly distressed by its description of his status. Although he has worked on BNFL-commissioned research projects in the past, Smith says he is an independent scientist and was not paid to advise BNFL on the Gardner report. A spokesman for BNFL said that its action was in line with a commitment to keep the Sellafield workforce fully informed (the press release was based on a letter sent to trade union representatives). But he added "we are sorry if he [Smith] is unhappy" and conceded "it may well have been better" to have described Smith's status differently.

Smith has now issued his own press
Mann's resignation causes uncertainty London

THE World Health Organization (WHO)'s Global Programme on AIDS faces an uncertain future following the resignation of its founding director, Jonathan Mann, last week. In his resignation letter to WHO director-general Hiroshi Nakajima, Mann cites the "great variance" between his own and Nakajima's positions on important areas of policy. Nakajima and Mann are understood to have disagreed, among other issues, on the programme's campaign to highlight the problems of AIDS in women, and links with other non-governmental organizations.

Mann's resignation has saddened AIDS researchers. Geoffrey Schild, of the UK Medical Research Council's directed programme on AIDS, describes Mann as "a very vigorous and effective campaigner on public health policy".

The choice of Mann's successor will have an important bearing on the future direction for the programme, which spends more than $\$ 100$ million a year, coordinating research and international efforts to slow the spread of the disease. Schild says "the leadership of WHO in this field is imperative".

Most recently, the programme has become involved with the development of AIDS policy in Eastern Europe (see Nature $344,95 ; 1990)$. Mann will remain as director until June.

Peter Aldhous

release which summarizes his views of the Gardner report. He concludes that the study was "well planned, well executed and well analysed". Some problems with the quantity of obstetric and questionnaire data were not surprising, given the 36-year timespan covered by the study. Smith writes "it would be prudent to assume the association with external radiation is causal" until more evidence is found, although he cannot rule out a chance association, or the effects of exposure to chemicals. He adds that further studies are needed on other groups of radiation workers.

BNFL also asked Sir Richard Doll, of the University of Oxford, to review the Gardner findings, and he has now reported back. Peter Aldhous

- LAST week's article on US reaction to the Sellafield childhood leukaemia study mentioned that the American Statistical Association (ASA) will have a session on radiation epidemiology at its August meeting in California; ASA has also scheduled a special conference on radiation and health in Copper Mountain, Colorado on 8-12 July at which Professor Martin Gardner, who headed the Sellafield team, will speak.

G. Christopher Anderson 